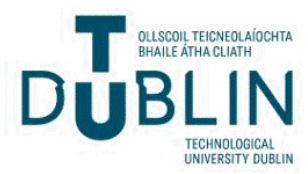

Technological University Dublin

ARROW@TU Dublin

Articles

School of Tourism \& Hospitality Management

2019

\section{Conceptualising talent in multinational hotel corporations}

\author{
Stefan Jooss \\ University College Cork \\ Anthony McDonnell \\ University College Cork \\ Ralf Burbach \\ Technological University Dublin, ralf.burbach@tudublin.ie
}

See next page for additional authors

Follow this and additional works at: https://arrow.tudublin.ie/tfschhmtart

Part of the Hospitality Administration and Management Commons, and the Tourism and Travel Commons

\section{Recommended Citation}

Jooss, S., McDonnell, A., Burbach, R. and Vaiman, V. (2019), "Conceptualising talent in multinational hotel corporations", International Journal of Contemporary Hospitality Management, Vol. 31 No. 10, pp.

3879-3898. DOI: 10.1108/IJCHM-10-2018-0849

This Article is brought to you for free and open access by the School of Tourism \& Hospitality Management at ARROW@TU Dublin. It has been accepted for inclusion in Articles by an authorized administrator of ARROW@TU Dublin. For more information, please contact arrow.admin@tudublin.ie, aisling.coyne@tudublin.ie, gerard.connolly@tudublin.ie.

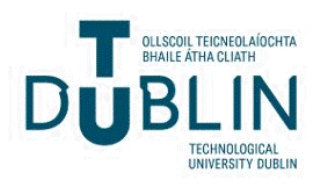




\section{Authors}

Stefan Jooss, Anthony McDonnell, Ralf Burbach, and Vlad Vaiman 


\title{
Conceptualising talent in multinational hotel corporations
}

Stefan Jooss and Anthony McDonnell

Cork University Business School, University College Cork, Cork, Ireland

Ralf Burbach

School of Hospitality Management and Tourism, Technological University Dublin, Dublin, Ireland, and

Vlad Vaiman

California Lutheran University, Thousand Oaks, California, USA

\begin{abstract}
Purpose - To identify, develop and retain talent, an important first step is to ensure that key stakeholders in the talent management (TM) process have a shared view of what is meant by talent within the organisation. The purpose of this paper is to conceptualise how talent is defined in the context of the hospitality industry and to examine the degree of (mis)alignment among corporate and business unit leaders.
\end{abstract}

Design/methodology/approach - The paper uses a qualitative approach consisting of 73 interviews with stakeholders at corporate and business unit levels in three multinational hotel corporations. In addition, documents were collected and analysed to support the interview data.

Findings - Each organisation had a formal approach to conceptualising talent at a corporate level. Both inclusive and exclusive views on talent as well as a broad set of characteristics that make up talent were reported with the importance of organisational values being prominent. However, despite formal global policies being in place, considerable divergence in practice was found across organisational levels.

Practical implications - A lack of clarity on what talent means in an organisational setting may lead to an inconsistent talent identification process which may lead to negative perceptions of fairness among employees. This may, in turn, bring about disgruntled employees and increased turnover.

Originality/value - This paper provides empirical evidence to the limited body of knowledge on the conceptualisation of talent. The display of organisational values emerged as important to being labelled talent, a factor that has received scant consideration in the literature.

Keywords Hotels, Multinational corporations, Talent management, Talent identification,

Multilevel case study, Talent conceptualisation

Paper type Research paper

\section{Introduction}

While talent has been identified as a critical source of competitive advantage by both practitioners and academics, organisations often appear to struggle to articulate the actual meaning of talent (Strack et al., 2013). As a result, talent management (TM), in practice, often appears to be " $a d$ hoc, unstructured and fragmented" (Jones et al., 2012, p. 399). Organisations seem to apply a "practical and pragmatic" approach to TM which focuses on short-term needs (Cooke et al., 2014, p. 234) rather than treating it in a more strategic way. TM can be defined as "the process through which organizations meet their needs for talent” (adapted from Cappelli and Keller, 2017, p. 28) with two strands dominating the discourse (McDonnell et al., 2017). The first strand focuses on key individuals or talent (Dries and Pepermans, 2012; Björkman et al., 2013; Tansley and 
IJCHM

31,10

3880

Tietze, 2013). The second strand focuses on the deployment of policies and procedures for managing these individuals (Vaiman and Collings, 2015; Cappelli, 2008; Collings and Mellahi, 2009). We argue that the development of an understanding what talent means and an appreciation of its importance are essential precursors to establishing an effective TM system. Scholars have asserted that research needs to address urgently how organisations in a particular setting actually understand talent (Thunnissen et al., 2013). However, the extant literature reveals a lack of clarity, conceptualisation and theorisation, along with a significant lack of empirical evidence with regard to the notion of talent (Festing et al., 2013; McDonnell et al., 2017).

This paper attempts to contribute to better conceptualisation of talent through focusing on the luxury hotel sector. The broader TM literature has also paid little attention to the hospitality industry despite its economic and social importance across the world. Moreover, the hospitality industry faces significant talent shortages and struggles to attract and retain talent because of a dynamic labour market and a poor industry image (Deery and Jago, 2015). The paper addresses the question, how do leaders across corporate and business unit levels conceptualise talent in multinational hotel corporations? By comparing and contrasting views of both levels, we aim to reveal the headquarters' view of what they perceive talent to be vis-à-vis how the concept of talent is understood at the business unit level. Understanding the "black box" of business unit approaches to talent (Tarique and Schuler, 2018, p. 95) appears critical, as it is supervisors and managers who implement TM practices. Using a multiple case study design enables us to elucidate alignment and misalignment in these organisations. Organisations often view their human resource management (HRM) practices as a valuable competence that they would like to replicate and exploit across business units. They seek consistency to strengthen their corporate culture and they aim to enhance equity and procedural justice in the firm (Björkman and Lervik, 2007). However, the extent to which this takes place in the context of how talent is defined and managed is unclear. A lack of clarity on what talent means in an organisation may lead to misalignment and an inefficient talent identification process and, thus, may hinder the establishment of a global talent pool. It may also lead to negative perceptions around fairness among employees in an organisation. The findings of this study can support leaders in better understanding the concept of talent and whether key stakeholders in the TM system are operating off the same perspectives.

\section{Understanding "talent"}

The term talent has had many different meanings over the centuries (Tansley, 2011). While described as a denomination of weight and a monetary unit in antiquity, the meaning changed from an inclination in the thirteenth century to a treasure in the fifteenth century and to a special natural ability in the seventeenth century. Terminological ambiguity around talent is evident in current debates, as it can refer to all people, a subset of people or a wide or narrow set of characteristics.

Gallardo-Gallardo et al.'s (2013) review depicts two overarching strands in the literature towards talent: the subject approach views talent as people, whereas the object approach depicts talent as characteristics that people have or not. Following the object approach, some scholars, particularly in the educational psychology literature, argue that these characteristics are innate and, therefore, refer to talent as natural abilities and gifts (Nijs et al., 2014). These innate abilities emerge at early ages (children and adolescents) are assumed to be very rare and allow outstanding performance in a particular domain, for example, music, sport, arts and science (Meyers et al., 2013). Other scholars contend that people's characteristics can be developed and refer to talent as mastery, that is, 
systematically advanced knowledge, skills and abilities (Silzer and Dowell, 2009; Schiemann, 2014). This will result in individual differences which is the approach mostly applied in the industrial and organisational psychology literature (Dries, 2013b). This approach also implies that talent needs to be proven over time, for example, by demonstrating consistent above-average performance (Dries and Pepermans, 2007). Other forms of the object approach are talent as commitment (Ulrich and Smallwood, 2012), talent as fit (Tansley et al., 2006) and talent as capital (Collings, 2014). Talent as commitment focuses on an individual's behaviour towards his or her work and the employing organisation. Ulrich and Smallwood (2012) describe commitment as the willingness to do a job. It also includes the perseverance and energy displayed while at work. Moreover, commitment acts as a barrier to leaving an organisation, that is, it is a positive predictor of retention (Gallardo-Gallardo et al., 2013). Talent as fit refers to a fit between an individual's talent and the operating context, that is, the right place, position and time (Coulson-Thomas, 2012). The organisational culture and the industry may have a significant impact on performance levels, and while individuals may demonstrate high performance in one context, they could potentially struggle in a different environment (Groysberg, 2010). Talent as capital focuses on the direct contribution of individuals to the organisational bottom line and is therefore often discussed in an organisational context (Lepak et al., 2011). While economists often refer to financial and physical capital, intellectual capital is an additional and intangible form of capital that helps to explain economic contribution (Blair, 2011). The terminology used to describe intellectual capital varies among scholars (i.e. human, social, political, cultural, structural and organisational capital) (Harvey and Novicevic, 2004; Farndale et al., 2010). However, human capital is often viewed as the central concept in contemporary organisations and the "linchpin" for all other forms of intellectual capital (Burton-Jones and Spender, 2011, p. 3). Human capital refers to "the value-generating potential of employee knowledge, skills and abilities” (Collings, 2014, p. 256).

Following the subject approach (Gallardo-Gallardo et al., 2013), organisations can be inclusive in their approach whereby talent refers to all employees. Firms may also be more exclusive where talent is viewed as a subset of people in their workforce (Iles $e$ t al., 2010). An inclusive approach generally encompasses a focus on everyone's strengths, an egalitarian distribution of resources and a collegial climate in the organisation (Buckingham and Vosburgh, 2001). A main point of critique of the inclusive perspective is the difficulty in differentiating TM from HRM (Silzer and Dowell, 2009), with Collings and Mellahi (2009) intimating that an inclusive approach may also often be less cost efficient and effective (Collings and Mellahi, 2009). A more exclusive approach focuses on segments or groups of the workforce, which often relates to high performers and high potentials (Ewerlin, 2013; Cappelli and Keller, 2017). The first dimension, performance, is linked to the quality and quantity of outputs (O'Boyle and Kroska, 2017). The second dimension, potential, refers to "the probable upper bound trajectory of what an individual may achieve during their career" (Finkelstein et al., 2018, p. 4). The argument put across for an exclusive approach is that it does not only allow a more effective allocation of resources, and thus provides a higher return on investment for the organisation, but it also creates a higher-performing workforce (Boudreau and Ramstad, 2005). However, an exclusive approach which focuses on a small subset or an elite group within the workforce may also lead to negative effects such as discouragement among other employees (Meyers and Van Woerkom, 2014). Moreover, concerns have been expressed with the two-dimensionality of the performance-potential construct (Clutterbuck, 2012), its delineation in organisations and the objectivity and science behind this. 
IJCHM

31,10

3882
Ultimately, it needs to be acknowledged that there are different takes on what talent means from a conceptual perspective. The use should and will vary depending on the organisational strategy and industry (Alziari, 2017). Hence, organisations themselves need to have a clear understanding of what talent entails in their particular setting giving consideration to both corporate and business unit views. A clear understanding of the term talent seems to be particularly important when an exclusive approach is applied as decisions on investment in a specific group of the workforce need to be made.

\section{Industry context}

Commensurate with the growth of tourism and the increased competition that hotel organisations face today is the need to find adequate talent to succeed (Bharwani and Butt, 2012; D'Annunzio-Green and Teare, 2018). As part of this process, a range of micro and macro factors must be considered, most notably a significant talent shortage of approximately 10 million people worldwide in the hospitality industry (Jayawardena et al., 2013). A considerable gap between the supply and demand of talent has been identified in both developed and emerging economies (Sheehan et al., 2018). This is a key concern in the industry as people have been identified as a critical source of competitive advantage, particularly in the luxury hotel sector where staff are expected to provide exceptional customer service (Bharwani and Butt, 2012; Horner, 2017).

The unique nature of this typical business-to-consumer industry is the elevated level of interaction between the guest and staff in providing the service in a $24 / 7$ environment (Pizam and Shani, 2009). In the twenty-first century, customers appear to be more sophisticated, travel experienced and demanding (Hein and Riegel, 2012; Reilly, 2018). Rather than providing a "simple" service, it is now imperative to create a positive and memorable experience for guests (Bharwani and Jauhari, 2013; Baum, 2006; D'AnnunzioGreen, 2018). Moreover, touchpoints - the moments when employees and guests interact are significant impact factors on the guest experiences and level of engagement (Bharwani and Jauhari, 2013; Ramdhony and D'Annunzio-Green, 2018). Successful TM and the ability to identify talent that can positively engage customers significantly impact the guest experiences and the long-term success of a hotel organisation (Reilly, 2018). However, there appears to be a disconnection between the importance of people and how they are managed in hotel organisations (Sheehan et al., 2018). Many employees are only employed on a parttime basis; students often view the industry only as an interstation while studying, and a poor perception of the industry exists in many countries (Barron, 2008). The hospitality industry has been traditionally described as a lower-skilled industry with a very dynamic labour market, poor remuneration, challenging work conditions and a volatile demand circle with distinctive seasons throughout the year (Deery and Jago, 2015). Consequently, the attraction, identification and retention of talent is a key challenge in the hospitality industry. This is particularly evident in large multinational hotel corporations. These are a growing segment within the hospitality industry as firms seek synergies through mergers and acquisitions to expand their market share forming even larger conglomerates (Dogru, 2017). These organisations need to manage the complexities of sourcing multi-skilled talent at a global scale.

\section{Methodology}

The paper adapts a qualitative research design involving multiple case studies. To select the participating organisations, this paper reviewed the Top 30 World Luxury Index of the most sought-after luxury hotel brands in 2014, which included both luxury 
and upper upscale brands (Digital Luxury Group and Laaroussi, 2014). These brands were managed by 18 firms. The study applied the following criteria to identify the case study organisations:

- a global presence (defined as operating multiple hotels across continents) to compare practices between headquarters and business units; and

- a portfolio of at least one luxury brand, as these hotels have the highest standards of service which requires skilled talent (Tungate, 2009; Walls et al., 2011).

This resulted in a sampling frame of 14 firms. Three of these agreed to participate. Because of confidentiality, the names of the organisations and interviewees have been altered. A unique name followed by a corresponding code was given to each organisation based on its headquarters location: American Hotel Group (A), APAC Hotel Group (B) and EMEA Hotel Group (C). American Hotel Group is the largest and longest established organisation in the sample and operates in more than 50 countries across six continents. APAC Hotel Group operates in more than 20 countries across five continents. The smallest and youngest firm in the sample is EMEA Hotel Group operating in more than 10 countries across two continents. All three firms are rapidly expanding their footprint through either acquisitions or new hotel openings.

The data collection phase involved 73 semi-structured interviews encompassing 18 (25 per cent) managers at a corporate level and 55 (75 per cent) managers at a business unit level. The interviewees were based in 15 countries: 35 (48 per cent) in EMEA, 20 (27 per cent) in APAC and 18 (25 per cent) in the Americas. An overview of all operations and human resource (HR) interviewees is presented in Table I. Each interviewee was assigned an individual code which provided information about his or her position, organisation and the order in which the interviews were conducted: for example, Head of HR A1 refers to the first participant at American Hotel Group. The Head of HR A1, Head of TM B3 and Head of TM C15 acted as gatekeepers by approving the research and assuring access to interviewees in the organisation. Provided with the levels as outlined above, these gatekeepers selected managers which they deemed appropriate based on their position, location and availability (referral sampling) (Marshall and Rossman, 2016). In addition to the interviews, we reviewed formal talent policies (documentation as outlined in Table II) that were provided by the main gatekeepers of the study.

We followed the thematic analysis process proposed by Braun and Clarke (2006). Thematic analysis was applied because it allowed both a rich description of the entire data set and a more nuanced approach of a specific area of interest such as the conceptualisation of talent (Braun and Clarke, 2006). The first stage involved the familiarisation with the interview data by listening to and transcribing all recordings and writing down initial notes while repeatedly reading the transcripts. The second stage included the generation of initial open codes which the authors used as a start list for further analysis. To avoid potential bias in the coding process, the initial codes were discussed among two of the authors to establish inter-rater reliability (Bazeley and Jackson, 2013; Podsakoff et al., 2003). A total of 63 open codes relating to the conceptualisation of talent were developed. The codes were labelled using the keywords referred to by the interviewees. These included:

Accomplishments, age, appearance, aspiration to grow and learn, asset management skills, behaviour-personality-attitude, business and commercial acumen, capability, care, chemistry, communication skills, competencies set, completed projects or training, core hospitality skills, cultural fit, customer focus, decision-making skills, education, emotional intelligence, 


\section{IJCHM \\ 31,10}

\begin{tabular}{|c|c|c|c|c|c|c|}
\hline Code & Position & Gender & Location & Tenure in firm & Interview date & Interview type \\
\hline A1 & Head of HR EMEA & Male & Switzerland & +25 Years & 03/08/2016 & Face-to-face \\
\hline A2 & Regional Head of HR & Female & Switzerland & +25 Years & 03/08/2016 & Face-to-face \\
\hline A3 & Cluster GM & Male & Switzerland & +25 Years & 03/08/2016 & Face-to-face \\
\hline A4 & Cluster HR Director & Female & Switzerland & +10 Years & 03/08/2016 & Face-to-face \\
\hline A5 & Front Office Manager & Female & Switzerland & +3 Years & 03/08/2016 & Face-to-face \\
\hline A6 & Cluster HR Director & Female & Russia & +10 Years & $24 / 08 / 2016$ & Skype \\
\hline A7 & Hotel Manager & Male & Russia & +10 Years & $24 / 08 / 2016$ & Skype \\
\hline A8 & Regional Head of HR & Female & China & +15 Years & $26 / 08 / 2016$ & Phone \\
\hline A9 & Head of HR APAC & Female & China & +15 Years & $26 / 08 / 2016$ & Skype \\
\hline $\mathrm{A} 10$ & Cluster HR Director & Male & China & +20 Years & $31 / 08 / 2016$ & Skype \\
\hline A11 & Regional Head of HR & Male & $\mathrm{UAE}$ & +10 Years & $31 / 08 / 2016$ & Skype \\
\hline $\mathrm{A} 12$ & $\begin{array}{l}\text { Rooms-Division } \\
\text { Director }\end{array}$ & Female & China & +25 Years & $02 / 09 / 2016$ & Skype \\
\hline A13 & GM & Male & Brazil & +15 Years & 02/09/2016 & Skype \\
\hline A14 & GM & Male & Australia & +15 Years & 05/09/2016 & Skype \\
\hline A15 & Cluster HR Director & Male & Thailand & +20 Years & 05/09/2016 & Skype \\
\hline A16 & Hotel Manager & Female & Brazil & +3 Years & 05/09/2016 & Phone \\
\hline A17 & Cluster HR Director & Male & Australia & +10 Years & 06/09/2016 & Skype \\
\hline A18 & F\&B Director & Male & Australia & +10 Years & 06/09/2016 & Skype \\
\hline A19 & Cluster HR Director & Male & Brazil & +25 Years & 06/09/2016 & Skype \\
\hline A20 & Head of TM & Male & USA & +5 Years & $12 / 09 / 2016$ & Face-to-face \\
\hline A21 & HR Director & Female & USA & +20 Years & $12 / 09 / 2016$ & Face-to-face \\
\hline A22 & $\begin{array}{l}\text { Head of HR the } \\
\text { Americas }\end{array}$ & Male & USA & +25 Years & $13 / 09 / 2016$ & Face-to-face \\
\hline A23 & GM & Male & USA & +30 Years & $14 / 09 / 2016$ & Face-to-face \\
\hline A24 & Hotel Manager & Male & USA & +15 Years & $14 / 09 / 2016$ & Face-to-face \\
\hline A25 & $\begin{array}{l}\text { Rooms-Division } \\
\text { Director }\end{array}$ & Male & USA & +20 Years & $14 / 09 / 2016$ & Face-to-face \\
\hline A26 & Regional Head of HR & Female & USA & +30 Years & 21/09/2016 & Phone \\
\hline A27 & F\&B Manager & Female & Germany & +5 Years & $23 / 09 / 2016$ & Face-to-face \\
\hline $\mathrm{A} 28$ & Cluster HR Director & Male & Germany & +10 Years & $29 / 09 / 2016$ & Skype \\
\hline A29 & GM & Male & Germany & +15 Years & $30 / 09 / 2016$ & Phone \\
\hline A30 & Cluster HR Director & Female & France & +20 Years & $13 / 10 / 2016$ & Phone \\
\hline B1 & L\&D Director & Female & USA & +10 Years & $02 / 09 / 2016$ & Skype \\
\hline $\mathrm{B} 2$ & F\&B Director & Male & UK & +5 Years & 07/09/2016 & Face-to-face \\
\hline B3 & Head of TM & Female & UK & +10 Years & 08/09/2016 & Face-to-face \\
\hline B4 & $\begin{array}{l}\text { Head of Operations } \\
\text { the Americas }\end{array}$ & Male & USA & +20 Years & $20 / 09 / 2016$ & Skype \\
\hline B5 & HR Director & Female & China & +20 Years & 21/09/2016 & Skype \\
\hline B6 & $\begin{array}{l}\text { Head of Operations } \\
\text { EMEA }\end{array}$ & Male & UK & +15 Years & $29 / 09 / 2016$ & Skype \\
\hline B7 & Hotel Manager & Male & USA & +15 Years & 06/10/2016 & Skype \\
\hline B8 & L\&D Manager & Female & USA & +5 Years & $12 / 10 / 2016$ & Skype \\
\hline B9 & Hotel Manager & Male & USA & +10 Years & $13 / 10 / 2016$ & Skype \\
\hline $\mathrm{B} 10$ & HR Director & Male & USA & +5 Years & $14 / 10 / 2016$ & Skype \\
\hline B11 & $\begin{array}{l}\text { Head of HR the } \\
\text { Americas }\end{array}$ & Female & USA & +2 Years & $19 / 10 / 2016$ & Skype \\
\hline B12 & HR Director & Male & USA & +15 Years & 20/10/2016 & Skype \\
\hline B13 & F\&B Director & Male & China & +10 Years & 03/11/2016 & Face-to-face \\
\hline B14 & GM & Male & China & +10 Years & 03/11/2016 & Face-to-face \\
\hline B15 & GM & Male & China & +10 Years & $03 / 11 / 2016$ & Face-to-face \\
\hline B16 & Group L\&D Manager & Male & China & +3 Years & $04 / 11 / 2016$ & $\begin{array}{l}\text { Face-to-face } \\
\qquad(\text { continued })\end{array}$ \\
\hline
\end{tabular}

Table I.

Overview of participants 


\begin{tabular}{|c|c|c|c|c|c|c|c|}
\hline Code & Position & Gender & Location & Tenure in firm & Interview date & Interview type & it \\
\hline B17 & Chief HR Officer & Male & China & +10 Years & 04/11/2016 & Face-to-face & \\
\hline B18 & $\begin{array}{l}\text { Head of Operations } \\
\text { APAC }\end{array}$ & Male & China & +10 Years & 04/11/2016 & Face-to-face & \\
\hline B19 & HR Director & Female & China & +10 Years & $04 / 11 / 2016$ & Face-to-face & \\
\hline B20 & Hotel Manager & Male & China & +5 Years & 04/11/2016 & Face-to-face & 388 \\
\hline $\mathrm{B} 21$ & GM & Female & China & +10 Years & 05/11/2016 & Face-to-face & 0 \\
\hline B22 & Head of HR EMEA & Female & Switzerland & +5 Years & $17 / 11 / 2016$ & Face-to-face & \\
\hline B23 & GM & Male & Switzerland & +10 Years & $17 / 11 / 2016$ & Face-to-face & \\
\hline B24 & HR Director & Male & Switzerland & +15 Years & $17 / 11 / 2016$ & Face-to-face & \\
\hline B25 & L\&D Manager & Female & Switzerland & +3 Years & $18 / 11 / 2016$ & Skype & \\
\hline $\mathrm{C} 1$ & HR Director & Female & Spain & +3 Years & $30 / 11 / 2016$ & Skype & \\
\hline $\mathrm{C} 2$ & GM & Male & Germany & +3 Years & $30 / 11 / 2016$ & Skype & \\
\hline $\mathrm{C} 3$ & Regional Head of TM & Male & UK & +5 Years & 07/12/2016 & Face-to-face & \\
\hline $\mathrm{C} 4$ & Talent Manager & Female & UK & +3 Years & 07/12/2016 & Face-to-face & \\
\hline $\mathrm{C} 5$ & Regional Head of HR & Female & UK & +15 Years & 07/12/2016 & Face-to-face & \\
\hline C6 & HR Director & Female & UK & +2 Years & 07/12/2016 & Face-to-face & \\
\hline $\mathrm{C} 7$ & HR Manager & Female & Germany & +2 Years & 09/12/2016 & Skype & \\
\hline $\mathrm{C} 8$ & Cluster GM & Male & China & +5 Years & $15 / 01 / 2017$ & Skype & \\
\hline C9 & GM & Male & Kuwait & +5 Years & $15 / 01 / 2017$ & Skype & \\
\hline $\mathrm{C} 10$ & HR Director & Male & Kuwait & +3 Years & $16 / 01 / 2017$ & Skype & \\
\hline $\mathrm{C} 11$ & HR Director & Male & China & +3 Years & $17 / 01 / 2017$ & Skype & \\
\hline $\mathrm{C} 12$ & Hotel Manager & Female & Spain & +5 Years & 23/01/2017 & Skype & \\
\hline $\mathrm{C} 13$ & GM & Male & UAE & +3 Years & 07/02/2017 & Face-to-face & \\
\hline $\mathrm{C} 14$ & HR Director & Female & $\mathrm{UAE}$ & +2 Years & 07/02/2017 & Face-to-face & \\
\hline C15 & Head of TM & Male & UAE & +3 Years & 08/02/2017 & Face-to-face & \\
\hline $\mathrm{C} 16$ & $\begin{array}{l}\text { Group Talent } \\
\text { Manager }\end{array}$ & Female & $\mathrm{UAE}$ & +2 Years & 08/02/2017 & Face-to-face & \\
\hline $\mathrm{C} 17$ & $\mathrm{GM}$ & Male & UAE & +15 Years & 08/02/2017 & Face-to-face & \\
\hline $\mathrm{C} 18$ & HR Director & Female & UAE & +2 Years & 08/02/2017 & Face-to-face & Table I. \\
\hline
\end{tabular}

\begin{tabular}{lllr}
\hline American Hotel Group & APAC Hotel Group & EMEA Hotel Group & \\
\hline Corporate values & Leadership competency framework & Leadership competency framework & \\
Leadership competency & Functional competency framework & Recruitment guide & Table II. \\
framework & Performance-potential grid & Behavioural interview guide & Performance management guide \\
Performance management & & Talent review guide & Selected formal talent \\
framework & & Potential rating form & policies \\
& & Performance-potential grid & (documentation) \\
\hline
\end{tabular}

empathy, engagement or commitment, entrepreneurial skills, experience, financial skills, flexibility and agility, global mind-set, going the extra mile, gut feeling, happiness, higher or more complex role, humility, individual goals and objectives, initiative, innovation and creativity skills, integrity, intuition, key performance indicators, language skills, leadership skills, local knowledge, maturity, mobility and transferability, operational skills, organising skills, passion, people skills, performance, positive attitude, potential, proactive attitude, problem-solving skills, readiness, revenue contributor, selling and upselling skills, seniority, service quality and productivity, social skills, strategic thinking skills, strategic value, team fit, teamwork skills, technical skills, understanding of luxury. 
IJCHM

31,10

3886

As part of the third stage, broader categories were developed to combine individual codes with similar meaning. These included:

Aspirations, black box (subjective decision), cognitive competence (knowledge), education, experience, functional competence (skills), intellectual abilities (intelligence), performance, potential, and social competence (attitudes and behaviours).

The fourth stage included an in-depth review of the data where further categorisation occurred, in addition to discarding codes that deemed less relevant to the conceptualisation of talent. The conceptualisations made across the three organisations included both subject and object approaches, elements of a competency framework (cognitive, functional and social competencies) and the two dimensions of performance and potential. The number of references made to each category provided a useful indication to the relative importance of the component, for example, very little reference was made to intellectual abilities, while most references were made to social competencies. The fifth stage included defining final themes and setting those into context in the entire case. We found alignment and misalignment across the three organisations and between the corporate and business unit levels which are presented in the findings section.

\section{Findings}

\section{Case A: American Hotel Group}

The corporate view. At a corporate level, formal global talent policies were in place. The exclusive talent policies illustrated a subject approach to talent, focused on heads of departments and above positions and aimed to identify "top talent" based on two principal indicators: performance and potential. Performance was assessed based on key business performance indicators and a competency framework which included five leadership competencies. There was no weighting applied to the individual components. No official definition or list of indicators for potential had been established.

A strong awareness of the formal global policies was found across the operating regions at a corporate level (i.e. at the global and regional headquarters) (Heads of HR A1, A9 and A22; Head of TM A20). However, while the formal approach clearly indicated an exclusive approach to talent, some of the corporate interviewees appeared to be uncomfortable with this and had a desire towards an inclusive view. These interviewees showed some discomfort when they were asked to conceptualise talent. Discussing the term "talent" was viewed as "nomenclature" by the Head of HR A9, and the broadness of talent in the hospitality industry was highlighted by the Regional Head of HR A2:

I think talent is broad, right? We talk about our talent in terms of those individuals who are top talent. When we talk about our employees, we talk about our associates. I suppose you could say everyone is a talent and there are certain individuals that are top talent. A top talent in general is somebody who has high potential and somebody who is medium to high performing. (Head of HR A9)

I think technically anybody could be a talent, but there are so many factors that play a role whether this talent comes to blossom. If there is somebody out there who has a talent for something very specific which is key for a successful delivery for a certain experience somewhere, maybe this person does not have the talent to become a general manager, but what am I to judge, to say that this person is not a talent. (Regional Head of HR A2)

Corporate interviewees referred to both subject and object approaches to talent. In alignment with the formal policies, the characteristics of talent frequently referred to were performance and potential (exclusive). A particular focus for all HR leaders at a corporate level was the 
demonstration of the organisational purpose and values to be considered talent. This was mainly assured by following the established leadership competency framework. Rather than focusing on traditional leadership skills, the five leadership competencies were strongly talent connected with the culture of the organisation and focused on behaviours that demonstrate these values (Heads of HR A1 and A22; Regional Head of HR A26). While the formal talent policies already illustrated the critical importance of the organisational values, corporate leaders indicated that this had not yet fully been integrated by all business unit managers:

If I look at it from a HR perspective, I think leadership is very important for me and somebody who understands the purpose of our company, who can live the values. Now for me, I wish that one day we would fire somebody over that even though he delivers results. That would be a strong statement. A deep sense of purpose that people buy into what you do as a company which is more than just selling hotel rooms. (Head of HR A1)

We always struggle with making sure that leaders are identifying our talent consistently and in some respect what I mean by that is: We have a tendency in our company to identify talent based on skills versus starting with, do they have the right values that we are looking for. (Head of HR A22)

The business unit view. Interviewees at a business unit level were not able to communicate the formal policies on conceptualising talent. Nevertheless, managers at a business unit level were aware of the formal purpose of the organisation to which people related to and the interviewees explained the impact of that on understanding talent:

We aim to be a company that is pursuing a higher purpose, being brand focused, and we look for talent that is emotionally connected with the brand, with the organisation. We are moving away from the technical skills-based profiles to the more emotion-based talent. (General Manager (GM) A13)

Business unit leaders mainly spoke around the object approach to talent, that is, referring to a range of characteristics of talent including skills and behaviours. Cluster HR Director A17 argued that operational managers were "not always recognising the behaviours that we are promoting":

Nowadays we are still struggling with the leadership that we are having in the company. We look for somebody who is able to inspire. I think our CEO has this very clear, but unfortunately not all the leaders in the company have the same vision. In the second level in the organisation, there are plenty of old-fashioned hoteliers and until they do not change their mind, we will not change. (Cluster HR Director Al9)

Several interviewees pointed out that there was little formality at a business unit level regarding talent. Some business units were implementing the leadership competencies, for example, as part of an interview process or performance reviews. However, the interviewees lacked an understanding of what talent entailed and how talent decisions were made (i.e. using the two dimensions of performance and potential). Consequently, interpretations of talent varied significantly. The dominating view was that attitude and behaviours were the most important components in the industry (Food and Beverage (F\&B) Director A18; Rooms-Division Director A25; Cluster HR Director A28; GM A29).

\section{Case B: APAC Hotel Group}

The corporate view. The formal global talent policies outlined an inclusive subject approach to conceptualising talent. The TM policies had been established for all employees. The two key dimensions were performance and potential. Performance referred to key business performance indicators or individual objectives and a competency framework both carrying 50 per cent weighting. The competency framework focused on organisational values (core 
IJCHM

31,10

competencies), behaviours (leadership competencies) and skills (position-specific functional competencies). Potential was only broadly defined as "the ability to move to a higher level".

While the formal approach to viewing talent, that is, a focus on the two indicators of performance and potential, was known at the global and regional headquarters, corporate interviewees tended to adopt somewhat different foci (Head of TM B3; Heads of HR B11 and B22; Chief HR Officer B17). The Head of TM B3 who centrally managed the TM process highlighted the importance of two types of talent: cultural exchange ambassadors and high potential talent. The former represents employees, who are high performing with a proven track record and who role model the organisational values, but do not necessarily have the ability or desire to grow further. The latter describes employees, who are likely to move up in the firm. The extent to which a focus on high potential talent is desirable and/or applied in the firm remained unclear. In alignment with the formal approach, an initially inclusive subject approach to talent was applied by the corporate leaders. However, focus was then placed on employees who would likely grow within the organisation. While the Head of HR B11 discussed "innate talents", the Head of HR B22 referred to a focus on a "future pipeline":

I think certainly everyone has talent, how we extract the basis of that talent is really up to us once they become a colleague. Once they are with us, it is up to us to find those innate talents and skills that these people have. (Head of HR B11)

From my perspective we define talent into different areas, different foci, but for me those valuable colleagues that are performing their day in, day out job, they are to me seen as talent. We develop all our talent, we develop all our colleagues, but there may be some that really fall under a focus of that future pipeline, so that is probably where the differentiation is. I think in my vision everyone is talent. (Head of HR B22)

The Head of Operations B18 admitted that he did not "completely understand anymore" how the word talent was applied in the organisation which implied a lack of clear communication around talent terminology even at a corporate level. It appeared that the desire to move up significantly impacted whether someone was considered talent and consequently included in a core talent pool:

Every one of our colleagues is a talent, we could not work without them, they bring value and they are top of the game or they would not be here. But where I get confused, we sometimes talk about talent as the people we want to develop and keep moving forward. My administrative assistant is absolutely fantastic, I could not work without her, but she never wants to do anything more than that and she has been doing that for fifteen years, so, I do not know how you use the word. (Head of Operations B18)

The business unit view. At a business unit level, there were considerable variations among the stakeholders with subject and object approaches to talent. Apart from a few interviewees (Learning and Development (L\&D) Directors B1 and B8), business unit managers had limited knowledge on any formal conceptualisation and terminology. GM B15 asserted that "every general manager does their own thing". Line managers tended to focus on a broad range of individual competencies rather than following the formal competency framework. Interviewees did not relate to the two dimensions of performance and potential which showed a considerable misalignment with the formal approach (e.g. Hotel Manager B7; HR Director B24):

What you cannot teach is that right amount of engagement and passion for this industry. Talent is someone who has that and the right people skills to eventually lead the department. Much more than functional skills in a certain capacity. It is emotional intelligence, leadership skills, motivational skills, and an overall right attitude that needs to come along. (Hotel Manager B7) 
It is a mix of having the competencies, and the right attitude and the passion and the motivation and all of these different ingredients. The willingness to shine. The willingness to delight the guest. It is a set of qualities, traits of character that altogether make a portrait. You look at the talent person. You have seen a person work. You have seen the person interact and you say, wow, he is a great fit for our company. (HR Director B24)

The inclusive versus exclusive debate as to whether all or only some employees should be considered talent was also a key concern in this organisation. Most interviewees at this level favoured an inclusive view (e.g. L\&D Director B1; HR Director B10; GM B23):

I am going to say that all of the employees are an asset, and they all bring different talents. They all have different sets of competencies. There may be sometimes a perception that some individuals are not bringing the talents, but I think it is may be more on the recruitment side. Are we really putting them in the right spots? Are they really a good fit? (L\&D Director B1)

I am an optimist and I think everyone has talent. I think that there might be situations sometimes where we are guilty of not applying the right talent in the right areas. So that is kind of a little bit on us with the talent assessment and how we make sure that they are the right fit. (HR Director B10)

To me everyone is talent. Everyone must be talent. I would not be a good manager saying, 'I do not hire talent' because if I want to be working for the best, I need to work with the best, and I am only as good as my weakest link. (GM B23)

While following an inclusive approach to talent, GM B21 pointed out that a nuanced view on talent must also be applied as different abilities are required for different positions. This raised the question as to whether talent could be defined equally across hierarchical levels and departments within an organisation.

Some are very good with guests, that is their talent, but you give them statistics, financially, a mess. So, I need those talents to be in the front, and I need people who are meticulous and who can do administration at the back. It is important that we are able to identify that particular skill in the person, and make sure that they are in the right job. It is not just about top management. (GM B21)

Hotel Manager B20 supported a more differentiated approach and contended that talent from a corporate perspective may be different to talent at a business unit level. On the one hand, "global talent" was required and ought to be monitored at a corporate level. On the other hand, talent at a business unit level depended on the "inherit need at the property".

I would look at talent almost as a niche skill if we talk about line staff and middle management. Something that others do not necessarily have or something that the market would demand and that is obviously gold dust on the market, so that is huge talent in my eyes for this market. (Hotel Manager B20)

Similarly, F\&B Director B13 preferred an exclusive approach to talent for the benefit of both employees and the organisation. He distinguished between employees who were performing well in their craft and talent who was "ambitious" and "wants to grow further". Corresponding with some of the corporate leaders, the notion of growing careers in the organisation appeared as a key differentiator and placed high importance on the potential dimension of talent:

You cannot build a team out of eleven star players. It would be a cut-throat environment. I do not think everybody is talent, but I think everybody has an important role to play within the organisation, and I think everybody contributes. It is still a place where you are expected to perform better than in any other property. (F\&B Director B13) 


\section{$\mathrm{IJCHM}$ 31,10}

\section{Case C: EMEA Hotel Group}

The corporate view. The global talent policies presented an inclusive subject approach for all employees. The formal indicators established were performance and potential. Performance was assessed using a competency framework (100 per cent weighting for line employees; 40 per cent for managers) and key business performance indicators (60 per cent weighting for managers). The competencies focused on three areas: organisational values, customers and innovation. Potential was referred to as the ability to move to a higher or more complex position. As part of the formal policies, a list of 10 indicators for potential was presented which focused on the areas of leadership, learning agility, communication, business acumen and flexibility.

The Head of TM C15 and Group Talent Manager C16 formed part of the small corporate HR leadership team and both confirmed the formal subject approach towards conceptualising talent. While the Group Talent Manager C16 believed that "a clear definition of what talent is" existed across the levels and regions in the organisation, the Head of TM C15 viewed talent as a concept that "is coming together with the puzzle pieces". In alignment with the established policies, the Head of TM C15 referred to performance and potential as the key dimensions of talent. While the initial talent process was set out to be inclusive, it was evident that a strong focus on these two dimensions was leading to a somewhat exclusive perspective. The two corporate leaders appeared to have distinct preferences when conceptualising talent. While the Head of TM C15 focused on talent at GM and executive committee levels (exclusive), the Group Talent Manager C16 applied a broader talent perspective (inclusive):

For a lot of people top talent is senior management, but I do not think so. We have to focus on everybody. What if all the waiters decide to leave - who is going to help us serve people in the hotel? Yes, senior management is important, but we must look at other populations [lower ranks] as well. (Group Talent Manager B16)

The business unit view. At a business unit level, there was evidence of a significant divergence of views. Even the Regional Head of TM C3 and the Regional Head of HR C5 who were based at a business unit were not aware of a formal approach to conceptualising talent intimating a lack of, or inefficient, communication between the headquarters and the business units around the meaning of talent. Following an inclusive subject approach to talent, the Regional Head of TM C3 assumed that business unit leaders were not aware of a formal approach which we subsequently confirmed in additional interviews:

I think what you will start finding is a lot of fragmented perceptions of what the different layers in our company think what talent is. From my perspective in the business, I would see everyone as talent, 100 per cent. I am not aware of what talent stands for within our company. (Regional Head of TM C3)

While some of the interviewees (e.g. GM C13; HR Director C14) followed a subject approach and equated talent with high potentials that can move to a higher role in the future, others focused on particular skills and behaviours (i.e. an object approach), for example, communication and innovation skills (HR Director C18) or the demonstration of the organisational values (GM C2). While some of these competencies were also represented in the formal competency framework, the business unit leaders were not able to fully explain the formal approach which arguably may lead to inconsistent talent identification processes.

Interviewees at a business unit level were also debating whether all or only some employees ought to be considered talent. Most interviewees followed the inclusive approach to talent (e.g. Regional Head of HR C5; HR Director C10). The key differentiator, again, 
appeared to be whether someone would like to grow their career in the organisation which highlighted the importance of the potential dimension of talent:

I think everybody has a talent. In terms of talent to grow in the business is a different question. There is not one individual that we employ that is not talented in some way, shape, or form. But somebody who has got strategic value to the business and wants to make a strategic career move with the business is part of a different group of people. (Regional Head of HR C5)

We do not have a formal written definition of what a talent is because I believe everyone has a talent and it can be very diverse. A cleaner has a talent to clean the windows very well. Not everybody can clean windows by the way, it sounds very easy, but it is not. Some employees may not even know that they have this talent for this role. (HR Director C10)

A more exclusive approach was applied by Cluster HR Director C8 who viewed talent at a senior management level as a "priority" to succeed in hotel openings. Hotel Manager C12 also supported an exclusive perspective and focused on innate abilities and above-average performers while also emphasising that a diverse set of talent was required in hotel organisations:

For me it is a person that can do something special. There is different talent, a concierge has a different talent than a housekeeping maid, and everyone has their own talent to be in the right place to work. It is their natural ability and they excel compared to the rest of the team. That is what I call talent. (Hotel Manager C12)

\section{Discussion}

This paper contributes to the conceptualisation of talent literature through an in-depth analysis of how talent is viewed by key stakeholders in the hospitality industry. It addressed the question of how corporate and business unit leaders conceptualised talent in multinational hotel corporations. By presenting a range of theoretical approaches to conceptualise talent in the literature section, we analysed the formal talent policies established by the three case study organisations and compared and contrasted these with the perspectives of interviewees at the headquarters and business units.

Reviewing the formal talent policies (see Table III for a summary), our findings suggest that the term talent is not explicitly and consistently defined in an organisational context and, thus, corresponds with what is said by many in the literature (Lewis and Heckman, 2006; Dries, 2013a, Schiemann, 2014).

The formal talent policies illustrate talent as people, that is, following the subject approach to talent (Gallardo-Gallardo et al., 2013). While one organisation focused on "top talent" (exclusive), two firms adopted an inclusive approach. However, it was also evident that the contribution towards the organisation was a key concept. In other words, it is not enough to be considered talent, but it must be proven in the organisational context through demonstrating performance and showing potential. This lends further support to the object approach and the literature on talent as capital which also views the contribution to the organisation as the core indicator (Dries, 2013b). To date, the literature lacks a clear distinction between performance and potential (Dries and Pepermans, 2012). In the case study organisations' formal talent policies, performance entails the demonstration of a competency framework and key business performance indicators. While the former relates to an individual's competency set, the latter is arguably also impacted by the context someone is operating in, and thus the reliability of this component is somewhat limited. We have similar, but enlarged, concerns with the second dimension, potential, for which a considerable lack of detail existed in the case study organisations. It appears as a very 


\section{IJCHM 31,10}

Table III.

Formal approach to conceptualising talent

\begin{tabular}{lll}
\hline American Hotel Group & APAC Hotel Group & EMEA Hotel Group \\
\hline TM for heads of & TM for all employees with two & TM for all employees with two \\
departments and above & key indicators to identify 'talent': & key indicators to identify 'talent': \\
with two key indicators to & performance and potential & performance and potential
\end{tabular}

\section{Performance}

Competency framework Weighting: $50 \%$

Four clusters: purpose, process, people, and personal Seven core competencies for everyone

Six to ten leadership competencies for supervisors and above

Position-specific functional competencies

Key business performance indicators or individual objectives

Weighting: 50\%

\section{Potential}

No official definition or list of indicators

\section{Potential}

At potential: the employee is working at the right level that is appropriate for their ability Good potential: the employee could move at least one more level up

High potential: the employee could move at least two levels up

\author{
Performance \\ Competency framework \\ Weighting: $100 \%$ for line \\ employees and supervisors; \\ $40 \%$ for managers \\ Three clusters: values, \\ customers, and innovation \\ Six competencies for line \\ employees and supervisors \\ Nine competencies for all \\ managers \\ Key business performance \\ indicators or individual \\ objectives \\ Weighting: $0 \%$ for line \\ employees and supervisors; \\ $60 \%$ for managers

\section{Potential} \\ Low potential: the employee \\ could move to a higher or more \\ complex position in more than \\ three years \\ Solid potential: the employee \\ could move to a higher or more \\ complex position in one to three \\ years \\ High potential: the employee \\ could move to a higher or more \\ complex position in less than one \\ year
}

vague construct which ultimately hinders a consistent conceptualisation of talent in a firm with much overlap with what performance is.

During the interviews at a corporate level, both the subject approach (talent as people) and the object approach (talent as characteristics of people) (Gallardo-Gallardo et al., 2013) were mentioned. The application of the organisational competency set which includes knowledge, skills and abilities (i.e. human capital) was emphasised, more so than the delivery of results. Focus was placed on the demonstration of behaviours that reflected the organisational values. Interviewees in the case study organisations detailed that TM approaches must be aligned with the purpose and values of the firm. Reviewing the formal talent policies, it is evident that values are seen as a foundational component to be considered talent. While the type of knowledge and skills may depend on the level and department in the organisation, values are critical across all positions in the case study organisations at both corporate and business unit levels. Each firm has developed a set of 
organisation-specific values which are either integrated or mirrored in the competencies requested. This shows the importance of organisational context when conceptualising talent (Vaiman and Collings, 2015) and deserves further attention in the TM literature.

At a business unit level, interviewees shared their own understanding of what they regarded as talent. While some of the interviewees referred to the subject approach, the majority viewed talent as characteristics of people, thus applying the object approach towards talent (GallardoGallardo et al., 2013). Despite the established formal approaches, there is a disjuncture between corporate and business unit levels, particularly at APAC Hotel Group and EMEA Hotel Group. The very centralised TM approach at these two organisations lacked some collaborative engagement across the corporate and business unit leaders which resulted in different inclusive and exclusive interpretations around talent. At American Hotel Group, interviewees also interpreted talent differently. However, a strong alignment around the organisational purpose and values and its demonstration as a key component of talent was found.

The misalignment between formal talent policies and business unit interpretations of talent was evident as the various characteristics of talent were not viewed in context of the formal competency framework but as individual interpretations by the managers. In contrast to the corporate leaders' focus on talent as capital, the interpretations of the business managers can be related to a variety of other theoretical streams, for example, talent as individual differences, as giftedness, as strength and as commitment. When describing the various competencies required, it was evident that the examples were closely related to the uniqueness of the hospitality sector, for example, passion for the industry, customer focus and delighting guests which shows the importance of the sectoral context.

\section{Conclusions and implications}

This paper investigated how leaders across corporate and business unit levels conceptualised talent in multinational hotel corporations. By doing so, the paper addressed the empirical gap on the understanding of talent in practice, and the findings add to the limited knowledge of TM conceptualisation in hotel organisations.

While a formal concept has been established, a lack of clarity across levels was evident with both subject and object approaches as well as inclusive and exclusive views on talent being present in the firms. The formal approaches to talent provide further support to the school of thought of talent as capital and the core dimensions of performance and potential (Collings, 2014). However, we also found a variety of other interpretations, particularly at a business unit level. In addition to the often-discussed individual components of knowledge, skills and abilities, this study presents the consideration of organisational values as a core element when conceptualising talent. Given its critical role in all case study organisations at both corporate and business unit levels, more attention to the impact of organisational values is needed. The multiplicity of talent in hospitality organisations was emphasised by leaders at both corporate and business unit levels. Before, during and after a hotel stay, guests experience strategically constructed touchpoints through employees in several functions. Interviewees referred to the variety of front of house positions (with direct customer interaction) and back of house positions (with administrative or strategic foci). To manage this multiplicity of talent, it is arguably required to establish a differentiated TM architecture (Sparrow and Makram, 2015; Collings et al., 2017) which allows the identification and development of distinct groups of talent in an organisation. The paper implies that a broader, multilevel approach to talent will assist scholars and practitioners to understand talent more comprehensively. Such an approach also requires to clearly distinguish between performance and potential, while demarcating between functional competencies which are specific to a position or department and broader 
IJCHM

31,10

\section{4}

dimensions of talent (e.g. demonstration of organisational values), which may be applicable across levels and functions.

Ultimately, there is no single perspective on talent, as it is a contested domain, and as such, a combination of subject and object approaches is present. However, the multiplicity of talent should not justify a lack of clarity on what talent means in an organisation, particularly if the objective is to identify talent on a global scale. Seeking alignment to replicate and exploit talent practices across business units leads to more consistency and potentially a more effective talent identification process. In contrast, a lack of clarity on what talent means in an organisation may lead to uneven and detrimental outcomes at the individual, unit and organisational levels: for example, ambiguity and misperceptions on talent status, negative perceptions around procedural fairness among employees and an inconsistent talent identification process (Thunnissen and Van Arensbergen, 2015). It is evident that the development of formal policies does not suffice, but active management of the implementation (observable behaviour), internalisation (degree of acceptance) and integration (link to existing practices) may be essential if a global, consistent perspective is desired (Björkman and Lervik, 2007).

The conceptualisation of talent needs to be further developed at a corporate level and cascaded down the various levels in the organisations to have a consistent approach across the organisation as well as engagement by all employees. To some extent, we found discomfort among interviewees when they were asked to conceptualise talent, as they wanted to avoid an exclusive view on talent. Interviewees across levels and organisations stated the concern of inclusivity of all employees and asserted that all employees provide value as part of the service chain. Organisations ought to address the low awareness of talent terminology at a business unit level and have discussions around what constitutes talent. Employees, on the other hand, should familiarise themselves with talent language in the organisation. While the multiplicity of talent in the hospitality industry should be valued, it appears necessary to have a broad global concept which is aligned with business strategies to consistently identify talent.

\section{Limitations and future research}

Like all research projects, there are limitations that are worthy of acknowledgement. While the paper benefits from rich, illustrative data, it does not present any quantitative evidence around the conceptualisation of talent. Moreover, the generalisation and theorisation of case study research has been questioned in the literature due the limited number of organisations involved in such studies. As only three organisations were able to commit to the research, replication of the study with more firms is required. We followed a process of referral sampling and relied on the judgement of the three gatekeepers to identify suitable participants based on their position, location and availability. The study focused on corporate and business unit leaders and, thus, did not include the large population of line employees. In addition, the research was conducted in various cultural settings, and thus, the interviewees' beliefs and assumptions may have been influenced by the cultural norms in a particular context.

While this study presents insights from three hotel corporations, more information on how other organisations in the hospitality sector, and indeed, other sectors on how they conceptualise talent would be useful to corroborate the findings (Thunnissen et al., 2013). Clarifying the term talent is critical when conducting TM studies. Ignoring this initial step leads to the danger of collecting results on TM practices that lack relevance in the actual organisational setting. More information regarding what each dimension of talent entails (e.g. performance and potential) is required. In addition, the inclusion of other staff members (i.e. line employees) would be valuable in comparing their perceptions on the concept of talent with the observations from the operational and HR managers (Sonnenberg et al., 2014; Khoreva et al., 2017). Organisations must ensure that employees experience a system that 
offers a "strategic climate for talent" (King, 2017, p. 301). The case study organisations focused on individual talent as part of their understanding of talent. Future studies could, therefore, evaluate talent from group or network perspectives.

\section{References}

Alziari, L. (2017), “A chief HR officer's perspective on talent management”, Journal of Organizational Effectiveness: People and Performance, Vol. 4 No. 4, pp. 379-383.

Barron, P. (2008), "Education and talent management: Implications for the hospitality industry", International Journal of Contemporary Hospitality Management, Vol. 20 No. 7, pp. 730-742.

Baum, T. (2006), "Reflections on the nature of skills in the experience economy: challenging traditional skills models in hospitality", Journal of Hospitality and Tourism Management, Vol. 13 No. 2, pp. 124-135.

Bazeley, P. and Jackson, K. (2013), Qualitative Data Analysis with NVivo, Sage Publications, Thousand Oaks, CA.

Bharwani, S. and Butt, N. (2012), "Challenges for the global hospitality industry: an HR perspective", Worldwide Hospitality and Tourism Themes, Vol. 4 No. 2, pp. 150-162.

Bharwani, S. and Jauhari, V. (2013), "An exploratory study of competencies required to co-create memorable customer experiences in the hospitality industry", International Journal of Contemporary Hospitality Management, Vol. 25 No. 6, pp. 823-843.

Björkman, I., Ehrnrooth, M., Mäkelä, K., Smale, A. and Sumelius, J. (2013), "Talent or not? Employee reactions to talent identification”, Human Resource Management, Vol. 52 No. 2, pp. 195-214.

Björkman, I. and Lervik, J.E. (2007), "Transferring HR practices within multinational corporations", Human Resource Management Journal, Vol. 17 No. 4, pp. 320-335.

Blair, M.M. (2011), “An economic perspective on the notion of 'human capital”, in Burton-Jones, A. and Spender, J. (Eds), The Oxford Handbook of Human Capital, Oxford University Press, Oxford.

Boudreau, J.W. and Ramstad, P.M. (2005), "Talentship, talent segmentation, and sustainability: a new HR decision science paradigm for a new strategy definition”, Human Resource Management, Vol. 44 No. 2, pp. 129-136.

Braun, V. and Clarke, V. (2006), "Using thematic interview analysis in psychology", Qualitative Research in Psychology, Vol. 3 No. 2, pp. 77-101.

Buckingham, M. and Vosburgh, R.M. (2001), "The 21st century human resources function: It's the talent, stupid!", Human Resource Planning, Vol. 24, pp. 17-23.

Burton-Jones, A. and Spender, J. (2011), "Introduction”, in Burton-Jones, A. and Spender, J. (Eds) The Oxford Handbook of Human Capital, Oxford University Press, Oxford.

Cappelli, P. (2008), "Talent management for the twenty-first century", Harvard Business Review, Vol. 86, pp. 74-81.

Cappelli, P. and Keller, J.R. (2017), "The historical context of talent management", in Collings, D.G., Mellahi, K. and Cascio, W.F. (Eds), The Oxford Handbook of Talent Management, Oxford University Press, Oxford.

Clutterbuck, D. (2012), The Talent Wave: Why Succession Planning Fails and What to Do about It, Kogan Page, London.

Collings, D.G. (2014), "Integrating global mobility and global talent management: exploring the challenges and strategic opportunities", Journal of World Business, Vol. 49 No. 2, pp. 253-261.

Collings, D.G. and Mellahi, K. (2009), "Strategic talent management: a review and research agenda", Human Resource Management Review, Vol. 19 No. 4, pp. 304-313.

Collings, D.G., Mellahi, K. and Cascio, W.F. (2017), "Introduction", in Collings, D.G., Mellahi, K. and Cascio, W. F. (Eds), The Oxford Handbook of Talent Management, Oxford University Press, Oxford. 
IJCHM 31,10

Cooke, F.L., Saini, D.S. and Wang, J. (2014), "Talent management in China and India: a comparison of management perceptions and human resource practices", Journal of World Business, Vol. 49 No. 2, pp. 225-235.

Coulson-Thomas, C. (2012), "Talent management and building high performance organisations", Industrial and Commercial Training, Vol. 44, pp. 429-436.

D'Annunzio-Green, N. (2018), "Cornerstones of talent management as a strategic priority in the hospitality”, Worldwide Hospitality and Tourism Themes, Vol. 10, pp. 5-13.

D'Annunzio-Green, N. and Teare, R. (2018), "Reflections on the theme issue outcomes: is talent management a strategic priority in the hospitality sector?", Worldwide Hospitality and Tourism Themes, Vol. 10, pp. 124-130.

Deery, M. and Jago, L. (2015), "Revisiting talent management, work-life balance and retention strategies", International Journal of Contemporary Hospitality Management, Vol. 27 No. 3, pp. 453-472.

Digital Luxury, G. and Laaroussi, S. (2014), The World Luxury Index Hotels 2014: The Most Soughtafter Luxury Hotels, Digital Luxury Group (DLG), Geneva.

Dogru, T. (2017), "Under- vs over-investment: hotel firms' value around acquisitions”, International Journal of Contemporary Hospitality Management, Vol. 29 No. 8, pp. 2050-2069.

Dries, N. (2013a), "Talent management, from phenomenon to theory: introduction to the special issue", Human Resource Management Review, Vol. 23 No. 4, pp. 267-271.

Dries, N. (2013b), "The psychology of talent management: a review and research agenda", Human Resource Management Review, Vol. 23 No. 4, pp. 272-285.

Dries, N. and Pepermans, R. (2007), "Real high-potential careers: an empirical study into the perspectives of organisations and high potentials", Personnel Review, Vol. 37 No. 1, pp. 85-108.

Dries, N. and Pepermans, R. (2012), "How to identify leadership potential: development and testing of a consensus model", Human Resource Management, Vol. 51 No. 3, pp. 361-385.

Ewerlin, D. (2013), "The influence of global talent management on employer attractiveness: an experimental study; der einfluss des global talent managements auf die arbeitgeberattraktivität: eine experimentelle untersuchung", Zeitschrift Für Personalforschung; German Journal of Research in Human Resource Management, Vol. 27 No. 3, pp. 279-304.

Farndale, E., Scullion, H. and Sparrow, P.R. (2010), "The role of the corporate HR function in global talent management", Journal of World Business, Vol. 45 No. 2, pp. 161-168.

Festing, M., Schäfer, L. and Scullion, H. (2013), "Talent management in medium-sized German companies: an explorative study and agenda for future research", International Journal of Human Resource Management, Vol. 24 No. 9, pp. 1872-1893.

Finkelstein, L.M., Costanza, D.P. and Goodwin, G.F. (2018), "Do your high potentials have potential? The impact of individual differences and designation on leader success", Personnel Psychology, Vol. 71 No. 1, pp. 3-22.

Gallardo-Gallardo, E., Dries, N. and González-Cruz, T.F. (2013), "What is the meaning of 'talent' in the world of work?", Human Resource Management Review, Vol. 23 No. 4, pp. 290-300.

Groysberg, B. (2010), Chasing Stars: The Myth of Talent and the Portability of Performance, Princeton University Press, Princeton, NJ.

Harvey, M.G. and Novicevic, M.M. (2004), "The development of political skill and political capital by global leaders through global assignments", International Journal of Human Resource Management, Vol. 15 No. 7, pp. 1173-1188.

Hein, S.G. and Riegel, C.D. (2012), "Human resource and organizational management content in the hospitality curriculum: how the professionals view it", Journal of Human Resources in Hospitality and Tourism, Vol. 11 No. 2, pp. 165-181.

Horner, S. (2017), "Talent management defined", in Horner, S. (Ed.), Talent Management in Hospitality and Tourism, Goodfellow Publishers, Oxford. 
Iles, P., Preece, D. and Xin, C. (2010), "Talent management as a management fashion in HRD: towards a research agenda", Human Resource Development International, Vol. 13 No. 2, pp. 125-145.

Jayawardena, C., McMillan, D., Pantin, D., Taller, M. and Willie, P. (2013), "Trends in the international hotel industry", Worldwide Hospitality and Tourism Themes, Vol. 5 No. 2, pp. 151-163.

Jones, J.T., Whitaker, M., Seet, P.S. and Parkin, J. (2012), "Talent management in practice in Australia: Individualistic or strategic? An exploratory study", Asia Pacific Journal of Human Resources, Vol. 50 No. 4, pp. 399-420.

Khoreva, V., Vaiman, V. and Van Zalk, M. (2017), "Talent management practice effectiveness: investigating employee perspective", Employee Relations, Vol. 39 No. 1, pp. 19-33.

King, K.A. (2017), "The talent climate: creating an organisational context supportive of sustainable talent development through implementation of a strong talent system", Journal of Organizational Effectiveness: People and Performance, Vol. 4 No. 4, pp. 298-314.

Lepak, D.P., Takeuchi, R. and Swart, J. (2011), “Aligning human capital with organizational needs”, in Burton-Jones, A. and Spender, J. (Eds), The Oxford Handbook of Human Capital, Oxford University Press, Oxford.

Lewis, R.E. and Heckman, R.J. (2006), "Talent management: a critical review", Human Resource Management Review, Vol. 16 No. 2, pp. 139-154.

McDonnell, A., Collings, D.G., Mellahi, K. and Schuler, R.S. (2017), "Talent management: a systematic review and future prospects", European J. Of International Management, Vol. 11, pp. 86-128.

Marshall, C. and Rossman, G.B. (2016), Designing Qualitative Research, Sage Publications, Thousand Oaks, CA.

Meyers, M.C. and Van Woerkom, M. (2014), "The influence of underlying philosophies on talent management: theory, implications for practice, and research agenda", Journal of World Business, Vol. 49 No. 2, pp. 192-203.

Meyers, M.C., Van Woerkom, M. and Dries, N. (2013), "Talent: innate or acquired? Theoretical considerations and their implications for talent management", Human Resource Management Review, Vol. 23 No. 4, pp. 305-321.

Nijs, S., Gallardo-Gallardo, E., Dries, N. and Sels, L. (2014), "A multidisciplinary review into the definition, operationalization, and measurement of talent”, Journal of World Business, Vol. 49 No. 2, pp. 180-191.

O’Boyle, E. and Kroska, S. (2017), "Star performers", in Collings, D.G., Mellahi, K. and Cascio, W.F. (Eds), The Oxford Handbook of Talent Management, Oxford University Press, Oxford.

Pizam, A. and Shani, A. (2009), "The nature of the hospitality industry: present and future managers' perspectives", Anatolia; an International Journal of Tourism and Hospitality Research, Vol. 20, pp. 134-150.

Podsakoff, P.M., Mackenzie, S.B., Lee, J. and Podsakoff, N.P. (2003), "Common method biases in behavioral research: a critical review of the literature and recommended remedies", Journal of Applied Psychology, Vol. 88 No. 5, pp. 879-903.

Ramdhony, A. and D'Annunzio-Green, N. (2018), “A dialogic reframing of talent management as a lever for hospitableness”, Worldwide Hospitality and Tourism Themes, Vol. 10 No. 1, pp. 14-27.

Reilly, P. (2018), "Building customer centricity in the hospitality sector: the role of talent management", Worldwide Hospitality and Tourism Themes, Vol. 10 No. 1, pp. 42-56.

Schiemann, W.A. (2014), "From talent management to talent optimization", Journal of World Business, Vol. 49 No. 2, pp. 281-288.

Sheehan, M., Grant, K. and Garavan, T.N. (2018), "Strategic talent management: a macro and micro analysis of current issues in hospitality and tourism", Worldwide Hospitality and Tourism Themes, Vol. 10 No. 1, pp. 28-41.

Silzer, R.F. and Dowell, B.E. (2009), Strategy-Driven Talent Management: A Leadership Imperative, John Wiley and Sons, Hoboken, NJ. 
IJCHM 31,10

3898

Sonnenberg, M., Van Zijderveld, V. and Brinks, M. (2014), “The role of talent-perception incongruence in effective talent management", Journal of World Business, Vol. 49 No. 2, pp. 272-280.

Sparrow, P.R. and Makram, H. (2015), "What is the value of talent management? Building value-driven processes within a talent management architecture", Human Resource Management Review, Vol. 25 No. 3, pp. 249-263.

Strack, R., Caye, J., Leicht, M., Villis, U., Böhm, H. and Mcdonnell, M. (2013), The Future of HR in Europe: Key Challenges through 2015, The Boston Consulting Group (BCG), Boston, MA.

Tansley, C. (2011), "What do we mean by the term 'talent' in talent management?", Industrial and Commercial Training, Vol. 43 No. 5, pp. 266-274.

Tansley, C., Harris, L., Stewart, J. and Turner, P. (2006), Talent Management: Understanding the Dimensions: Change Agenda, Chartered Institute of Personnel and Development (CIPD), London.

Tansley, C. and Tietze, S. (2013), "Rites of passage through talent management progression stages: an identity work perspective”, International Journal of Human Resource Management, Vol. 24 No. 9, pp. 1799-1815.

Tarique, I.R. and Schuler, R.S. (2018), "A multi-level framework for understanding global talent management systems for high talent expatriates within and across subsidiaries of MNEs: propositions for further research", Journal of Global Mobility: The Home of Expatriate Management Research, Vol. 6 No. 1, pp. 79-101.

Thunnissen, M., Boselie, P. and Fruytier, B. (2013), "Talent management and the relevance of context: towards a pluralistic approach", Human Resource Management Review, Vol. 23 No. 4, pp. 326-336.

Thunnissen, M. and Van Arensbergen, P. (2015), "A multi-dimensional approach to talent: an empirical analysis of the definition of talent in Dutch academia”, Personnel Review, Vol. 44 No. 2, pp. 182-199.

Tungate, M. (2009), Luxury World, Kogan Page, London.

Ulrich, D. and Smallwood, N. (2012), "What is talent?”, Leader to Leader, Vol. 63, pp. 55-61.

Vaiman, V. and Collings, D.G. (2015), "Global talent management”, in Collings, D.G., Wood, G. and Caligiuri, P.M. (Eds), The Routledge Companion to International Human Resource Management, Taylor and Francis, Milton Park.

Walls, A., Okumus, F., Wang, Y. and Kwun, D.J. (2011), "Understanding the consumer experience: an exploratory study of luxury hotels", Journal of Hospitality Marketing and Management, Vol. 20 No. 2, pp. 166-197.

\section{Appendix. Selected semi-structured interview questions}

- Does your organisation currently have a formal definition of talent in place? If so, how has it been communicated within the organisation?

- How would you define talent?

- What role does talent management play in your organisation?

- Could you describe the talent management strategy of the organisation?

- What strategies and criteria do you use to identify talent in different levels and departments of the organisation?

Corresponding author

Stefan Jooss can be contacted at: stefan.jooss@ucc.ie

For instructions on how to order reprints of this article, please visit our website:

www.emeraldgrouppublishing.com/licensing/reprints.htm

Or contact us for further details: permissions@emeraldinsight.com 